\title{
Detection of Sequence-Specific Gene by Multi-Channel Electrochemical DNA Chips
}

\author{
Xuzhi Zhang, ${ }^{*}$ Xinming Ji, Zhengguo Cui, Bing Yang, and Jie Huang \\ Yellow Sea Fisheries Research Institute, Chinese Academy of Fishery Sciences, No.106, Nanjing Rd, Qingdao 266071, China \\ *E-mail: zhangxz@ysfri.ac.cn \\ ${ }^{\dagger}$ The State Key Laboratory of ASIC \& System, Department of Microelectronics, Fudan University, Shanghai 200433, China \\ Received September 1, 2011, Accepted November 1, 2011
}

\begin{abstract}
Five-channel electrochemical chips were fabricated based on the Micro-electromechanical System (MEMS) technology and were used as platforms to develop DNA arrays. Different kinds of thiolated DNA strands, whose sequences were related to white spot syndrome virus (WSSV) gene, were separately immobilized onto different working electrodes to fabricate a combinatorial biosensor system. As a result, different kinds of target DNA could be analyzed on one chip via a simultaneous recognition process using potassium ferricyanide as an indicator. To perform quantitative target DNA detection, a limit of $70 \mathrm{nM}(\mathrm{S} / \mathrm{N}=3)$ was found in the presence of $600 \mathrm{nM}$ coexisting noncomplementary ssDNA. The real samples of loop-mediated isothermal amplification (LAMP) products were detected by the proposed method with satisfactory result, suggesting that the multichannel chips had the potential for a high effective microdevice to recognize specific gene sequence for pointof-care applications.
\end{abstract}

Key Words : DNA chips, WSSV gene, Multi-channel electrochemical detection, Electroanalysis, Loop-mediated isothermal amplification

\section{Introduction}

Currently, the need for sequence-specific DNA detection has resulted in considerable research efforts into developing hybridization biosensors. Optical biosensor based on fluorescence detection has arguably become the standard technique for quantifying extents of hybridization between surface-immobilized probes and fluorophore-labeled analyte targets. However, the fluorescence-based optical detection technique requires expensive equipment and sophisticated numerical algorithms to interpret the data, which makes the process time and cost ineffective. ${ }^{1-4}$ Electrochemical technique, which provides simplicity, accessibility and low cost, ${ }^{1}$ presents the advantages of simultaneous detection of numbers of markers, minute volume $(\mu \mathrm{L})$ utilization of samples and rapid response over the traditional fluorescence-based optical detection technique. ${ }^{5,6}$ Therefore, a lot of achievements have been obtained in the detection of DNA by electrochemical methods. ${ }^{5,7-13}$ Over the past years, our research groups have also focused on the development of electrochemical DNA hybridization biosensors. ${ }^{14}$ In the study, single-walled carbon nanotubes array was used as working electrode to immobilize probe DNA with a non-covalent mode. Thus the biosensor could be switched to detect different target DNAs easily. However, toward the goal of performing several target DNA analysis, this method suffered from a long assay time as compared with the DNA chips.

The analysis of complex DNA samples, such as the acquisition of sequence and expression information, requires the integration of multiple biosensors in connection with DNA arrays. ${ }^{15}$ Recently, DNA chips especially attract attention. ${ }^{3,4,12}$ A number of terms, like DNA arrays, gene chips or biochips, are often being intermixed to describe these devices. The most attractive features of these devices are the miniaturization, speed and accuracy. Accordingly, this DNA microchip technology offers an enormous potential for rapid multiplex analysis of nucleic acid samples, including the diagnosis of genetic diseases, detection of infectious agents, measurements of differential gene expression, drug screening and forensic analysis. Such use of DNA microarrays is thus revolutionizing many aspects of genetic analysis. ${ }^{12,16}$ However, to the best of our knowledge, there weren't reports on the selective detection of several target DNA fragments on one chip via a simultaneous recognition process using potassium ferricyanide as an electrochemical indicator.

In this study, photolithography technique was utilized to fabricate an integrated microelectrode array. On a chip five individual $\mathrm{Au}$ working electrodes shared a reference electrode and an auxiliary electrode. Different thiolated probe DNA fragments could be immobilized onto the working electrode at the same time and be used to recognize their complementary DNA (target DNA) simultaneously.

White spot syndrome virus (WSSV) is the causative agent of a deadly disease of cultured penaeid shrimp. ${ }^{17}$ Recently we have made an effort to establish economical and portable approaches to detect it. ${ }^{18}$ In this paper, the fabrication of the electrochemical chip enables us to develop miniaturization and mass production of DNA arrays for the gene detection. Real samples of loop-mediated isothermal amplification (LAMP) products related to WSSV were detected successfully by the proposed method. Results indicate that this device provides reliable information related to different target DNA via one recognizing performance. Now the establishment of the corresponding software for the simult- 
aneous scan is proceeding.

\section{Experimental}

Apparatus and Chemical. Cyclic voltammetry (CV), differential pulse voltammetry (DPV) and electrochemical impedance spectroscopy (EIS) were performed using a CHI 660D Electrochemical Analyzer (CH Instruments, Shanghai, China). All chips were fabricated by conventional photolithography.

6-Mercapto-1-Hexanol (MCH) was purchased from Sigma. Tris (2-carboxyethyl) phosphine Hydrochloride (TCEP) was from Tokyo Chemical Industry Co., Ltd. Betaine was purchased from Sigma-Aldrich (U.S.A.). Deoxyribonucleotide triphosphates (dNTPs) were purchased from MBI Fermentas (U.S.A.) and Bst DNA Polymerase was from New England Biolabs (NEB, U.S.A.). The other usual reagents were purchased from Shanghai Chemical Reagent Co. (Shanghai, China) and were all of analytical reagent grade. Solutions were all prepared with Millipore ultrapure water (Resistivity: $18 \mathrm{M} \Omega \cdot \mathrm{cm}$ ). DNA immobilization buffer: $10 \mathrm{mM}$ Tris-HCl, $1 \mathrm{mM}$ EDTA, $10 \mathrm{mM}$ TCEP (or dithiothreitol, DTT), and $1 \mathrm{M} \mathrm{NaCl}$ (pH 7.4). Hybridization buffer: phosphate buffered saline (PBS, pH 7.4) with $0.25 \mathrm{M} \mathrm{NaCl}$ and $10 \mathrm{mM}$ phosphate buffer. Synthetic oligonucleotides were purchased from Beijing SBS Genetech Co., LTD. (Beijing, China). The sequences of WSSV (VP35 gene) related primers are as follows (Table 1).

Fabrication of the Chips. All chips were fabricated by conventional photolithography. A fabrication flowchart for the micro electrochemical chip is shown in Figure 1(a). A $\mathrm{SiO}_{2}$ thin film with a $750 \mathrm{~nm}$ thickness was fabricated using the thermal oxidation process as an insulation layer on a ptype (100) wafer. A thin film working electrodes, gold layers with a thickness of $250 \mathrm{~nm}$ and an adhesion layer Ti with a $20 \mathrm{~nm}$ thickness, were then deposited by $e$-beam evaporation process, followed by being patterned using a liftoff process. In the similar way, reference electrodes $(5 \mathrm{~nm} \mathrm{Ti} / 15$ $\mathrm{nm} \mathrm{Ni} / 1.2 \mu \mathrm{m} \mathrm{Ag})$ and counter electrode $(20 \mathrm{~nm} \mathrm{Ti} / 200 \mathrm{~nm}$
Pt) were formed by lift-off process. To improve the metallic layer adhesion, intermediate layers of $\mathrm{Ti}$ and $\mathrm{Ni}$, respectively, had been used. Thereafter, a passivation layer to protect against conduction between the electrodes was formed based on $\mathrm{SiO}_{2}$ films using the plasma enhanced chemical
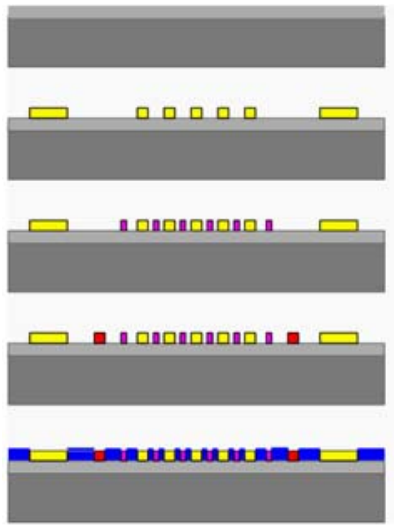

(a)

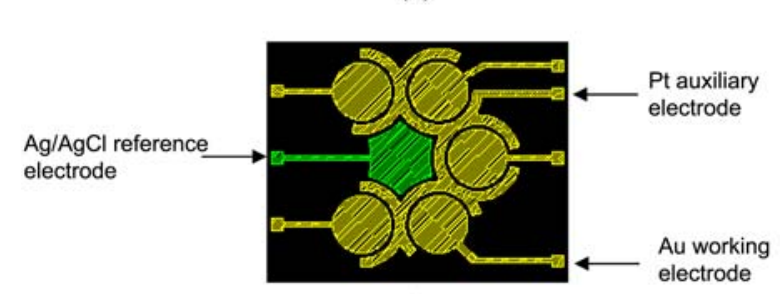

(b)

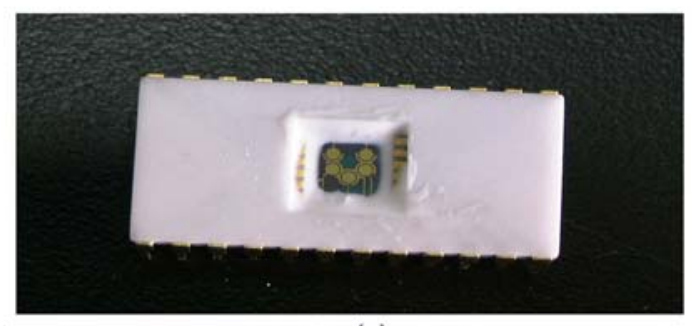

(c)

(a) Depositing of $\mathrm{SiO}_{2}$ with $7600 \AA$ thickness layer by thermal oxidation

(b) Depositing of Ti/Au 200/7600 $\AA$ working electrode and patterning the electrode by lift-off technique

(c) Depositing of Ti/Pt 200/2000 ̊ counter electrode and patterning the electrode by lift-off technique

\section{(d) Depositing of Ti/Ni/Ag 50/150/} 12000 Á reference electrode and patterning the electrode by life-off technique

(e) Depositing of $\mathrm{Si}_{3} \mathrm{~N}_{4} 2 \mu \mathrm{m}$ passivation layer by PECVD and opening the electrodes using RIE

Figure 1. Fabrication flowchart (a), structure profile (b) and picture (c) of the five-channel electrochemical chip.

Table 1. WSSV related primers used in the experiment

\begin{tabular}{|c|c|}
\hline Primer & Sequence \\
\hline probe 1 & 3'-OH-( $\left(\mathrm{CH}_{2}\right)_{3}$-S-S-( $\left(\mathrm{CH}_{2}\right)_{3}$-TTTGAATTCGTTTGATGGAGGGGTTACT-5' \\
\hline target 1 & 5'-CTTAAGCAAACTACCTCCCCAATGATGACTACGATGAGT-3' \\
\hline one-base mismatch & 5'-CTTAAGCAAGCTACCTCCCCAATGATGACTACGATGAGT-3' \\
\hline two-base mismatch & 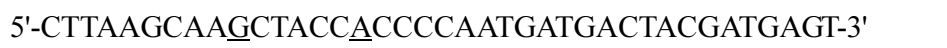 \\
\hline three-base mismatch & 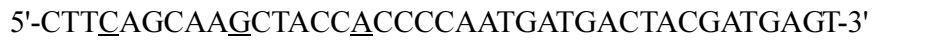 \\
\hline probe 2 & 3'-OH-( $\left(\mathrm{CH}_{2}\right)_{3}$-S-S- $\left(\mathrm{CH}_{2}\right)_{3}$-TTTTGAATTCGTTTGATGGAGGGGTTAC-5' \\
\hline target 2 & 5'-ACTTAAGCAAACTACCTCCCCAATGTACGTCGTACT GAC-3' \\
\hline probe 3 & 3'-OH-( $\left(\mathrm{CH}_{2}\right)_{3}$-S-S-( $\left(\mathrm{CH}_{2}\right)_{3}$-TTTTGCACCATCATTCGGCGTCACTCAA-5' \\
\hline target 3 & 5'-ACGTGGTAGTAAGCCGCAGTGAGTT-3' \\
\hline probe 4 & 3'-OH-( $\left(\mathrm{CH}_{2}\right)_{3}$-S-S- $\left(\mathrm{CH}_{2}\right)_{3}$-TTTTAAAATATATAGGTCAAACAATTCC-5' \\
\hline target 4 & 5'-ATTTTATATATCCAGTTTGTTAAGG-3' \\
\hline probe 5 & 3'-OH-( $\left(\mathrm{CH}_{2}\right)_{3}$-S-S- $\left(\mathrm{CH}_{2}\right)_{3}$-TTTGAAAGACAAGATGCCGTTGAAGTAT-5' \\
\hline target 5 & 5'-CTTTCTGTTCTACGGCAACTTCATA-3' \\
\hline
\end{tabular}


vapor deposition (PECVD) process, where the conditions were a deposition pressure and temperature of $3.8 \mathrm{mTorr}$ and $400{ }^{\circ} \mathrm{C}$, respectively, and an RF power and deposition ratio of $200 \mathrm{~W}$ and $125 \AA / \mathrm{s}$, respectively. A photoresist film with a $1.2 \mu \mathrm{m}$ thickness was spin coated for the opening pad area and patterned using a mask and ultra violet lithography. As shown in Figure 1 (b and c), on each chip five individual Audisc working electrodes with a diameter of $800 \mu \mathrm{m}$, a common $\mathrm{Pt}$ counter electrode and an $\mathrm{Ag} / \mathrm{AgCl}$ reference electrode were arranged. For the investigations in aqueous media, all microelectrodes were contacted via bond pads to a printed circuit.

Preparation of the Platform. Au is readily functionalized with thiolated DNA strands via the well known gold-sulfur chemistry. ${ }^{5,19-21}$ Thiolated probe DNA was immobilized onto clean working electrode separately with a modified method reported previously. ${ }^{20}$ Briefly, two microliters immobilization buffer containing $1.0 \mu \mathrm{M}$ probe DNA was coated onto the surface of the desired working electrode to obtained appropriate density. After an incubation for $1 \mathrm{~h}$, the platform was washed with water carefully. After this step we obtained an electrode immobilized with probe DNA, which was described as pDNA/Au. Then it was further treated with 1 $\mathrm{mM} \mathrm{MCH}$ for $1 \mathrm{~h}$ to obtain well aligned DNA self-assembly monolayers, ${ }^{22-24}$ followed by being rinsed with water carefully again. After that step the electrode was described as $\mathrm{MCH}+\mathrm{pDNA} / \mathrm{Au}$. Unless otherwise indicated, chips were immediately used for measurement or DNA hybridization after being dried with nitrogen.

Hybridization. Unless otherwise indicated, $2.0 \mu \mathrm{L}$ hybridization buffer solution containing desired concentration of target DNA was transferred onto the $\mathrm{MCH}+\mathrm{pDNA} / \mathrm{Aus}$ separately on the chip and incubated with gently shaking for $45 \mathrm{~min}$ at $42{ }^{\circ} \mathrm{C}$. ${ }^{14}$ Then the chip was washed with hybridization buffer solution containing $0.5 \%$ sodium dodecylsulfate (SDS), followed by being rinsed with water carefully. After this step the related electrode was described as $\mathrm{MCH}+\mathrm{dsDNA} / \mathrm{Au}$. The control experiments were performed with the same process by using noncomplementary ssDNA (ncDNA) or mismatched ssDNA instead of target DNA and the obtained electrode was described as $\mathrm{MCH}+\mathrm{ssDNA} / \mathrm{Au}$. Unless otherwise indicated, chips were immediately measured after being dried with nitrogen.

LAMP and Product Detection. All LAMP experiments were performed according to Ref. ${ }^{25}$ with minor modification. In brief, the final LAMP reaction (total, $25 \mu \mathrm{L}$ ) contained the three primer pairs in the following concentrations: 0.2 $\mu \mathrm{M}$ outer primers, $0.8 \mu \mathrm{M}$ loop primers, $1.6 \mu \mathrm{M}$ inner primers and $0.2 \mathrm{mM}$ of each dNTPs. The reaction mix also contained $2.5 \mu \mathrm{L}$ of $10 \times$ Bst DNA polymerase reaction buffer, $1 \mu \mathrm{L}$ of an $8 \mathrm{U} / \mu \mathrm{L}$ concentration of $B s t$ DNA polymerase, $6 \mathrm{mM} \mathrm{Mg}^{2+}, 0.4 \mathrm{mM}$ betaine and $1 \mu \mathrm{L}$ of template DNA sample $\left(1.8 \times 10^{-10} \mathrm{~g} / \mathrm{L}\right)$. The LAMP reaction mix was incubated at $65^{\circ} \mathrm{C}$ in a laboratory water bath for $35 \mathrm{~min}$.

The hybridization detection of the LAMP product samples of WSSV gene was further performed according to Ref.. ${ }^{26}$ In brief, samples were diluted with $5.0 \mathrm{mM}$ Tris- $\mathrm{HCl}$ buffer solution ( $\mathrm{pH}$ 7.4) and denatured by heating it in boiling water bath for $10 \mathrm{~min}$, and then frozen in an ice bath for 2 $\mathrm{min}$. Then the solution of the denatured LAMP products was dropped onto the modified surface of the chip for hybridization. The sequences of ssDNA probe immobilized on the chips were summarized in Table 2.

Electrochemical Measurements. Unless otherwise indicated, CV experiments were performed at a scan rate of 0.10 V/s; DPV experiments were performed at a pulse amplitude of $0.05 \mathrm{~V}$, a pulse width of $0.05 \mathrm{~s}$ and a pulse period of $0.2 \mathrm{~s}$. The EIS measurements were carried out in a $1.0 \mathrm{mM}$ $\mathrm{K}_{3}\left[\mathrm{Fe}(\mathrm{CN})_{6}\right]$ solution containing $0.5 \mathrm{M} \mathrm{KCl}$. The AC voltage amplitude was $5 \mathrm{mV}$ and the voltage frequencies were ranged from $10 \mathrm{KHz}$ to $0.05 \mathrm{~Hz}$. The applied potential was selected as $199 \mathrm{mV}$ from the formal potential of the redox probe $\left[\mathrm{Fe}(\mathrm{CN})_{6}\right]^{3-/ 4-}$. The electrochemical measurements of five electrodes were performed one-by-one and all experiments were conducted at room temperature $\left(25 \pm 0.5^{\circ} \mathrm{C}\right)$.

\section{Results and Discution}

Characterization of the Chip. $1.0 \mathrm{mM} \mathrm{K}_{3}\left[\mathrm{Fe}(\mathrm{CN})_{6}\right]$ was used to probe the electrochemical properties of the chips by $\mathrm{CV}$ technique. In these measurements, five working electrodes were scanned separately from $0.55 \mathrm{~V}$ to $-0.20 \mathrm{~V}$. As shown in Figure 2, 5 pairs of redox peaks present at $218 \pm 2$ $\mathrm{mV}$ and $145 \pm 2 \mathrm{mV}$ in the $0.1 \mathrm{M} \mathrm{KCl}$ supporting electrolyte with a peak potential separation $\left(\Delta E_{\mathrm{p}}\right)$ of $73 \pm 1 \mathrm{mV}$, suggesting a rather ideal surface structure of the working electrodes. And the ratio of the peak current values of cathodic and anodic ( $i_{\mathrm{pc}}$ and $i_{\mathrm{pa}}$ ) at each curve is close 1, also confirming the conclusion mentioned above. The peak currents of $i_{\mathrm{pc}}$ and $i_{\mathrm{pa}}$ vary slightly among different electrodes $(\leq 7 \mathrm{nA})$ and the cyclic voltammograms at all electrodes show almost identical waves, indicating that they can be used in parallel. The electrochemical areas of the working electrodes have been evaluated by chronoamperometry in a $1.0 \mathrm{mM}$ ferrocene monocarboxylic acid solution. The slope of the linear region of the $\mathrm{I}-\mathrm{t}^{-1 / 2}$ plot in the short time region provides the product $n F A C_{0} D^{1 / 2} \pi^{-1 / 2}$ using the Cottrell equation ${ }^{27}$ :

$$
i_{\mathrm{d}}=n F A C_{0} D^{1 / 2} \pi^{-1 / 2}
$$

Table 2. WSSV related probes and mismatch probe immobilized on the chips

\begin{tabular}{ll}
\hline Probe & Sequence \\
\hline probe $\mathrm{B}$ & $3^{\prime}-\mathrm{OH}-\left(\mathrm{CH}_{2}\right)_{3}-\mathrm{S}-\mathrm{S}-\left(\mathrm{CH}_{2}\right)_{3}-\mathrm{TTTCTATCGCCAGGTGAGGTAGA-5'}$ \\
probe F & $3^{\prime}-\mathrm{OH}-\left(\mathrm{CH}_{2}\right)_{3}-\mathrm{S}-\mathrm{S}-\left(\mathrm{CH}_{2}\right)_{3}-\mathrm{TTTGCACGCAATGGAGATGACAT-5}$ \\
mismatch probe & $3^{\prime}-\mathrm{OH}-\left(\mathrm{CH}_{2}\right)_{3}-\mathrm{S}-\mathrm{S}-\left(\mathrm{CH}_{2}\right)_{3}-\mathrm{TTTACCCTCACTGTAGAAGCAAT-5'}$ \\
\hline
\end{tabular}




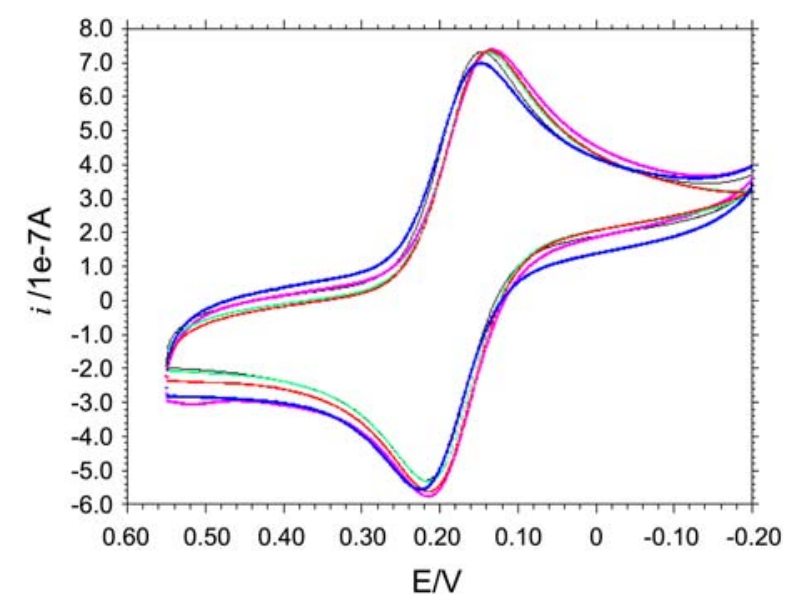

Figure 2. $\mathrm{CV}$ responses of $1.0 \mathrm{mM} \mathrm{K}_{3}\left[\mathrm{Fe}(\mathrm{CN})_{6}\right]$ at the five individual working electrodes on one chip in the $0.1 \mathrm{M} \mathrm{KCl}$ supporting electrolyte.

where $C_{0}=1.0 \mathrm{mM}, D=7.96 \times 10^{-10} \mathrm{~cm}^{2} \mathrm{~s}^{-1}$, are respectively, the concentration and diffusion coefficient of ferrocene monocarboxylic acid, and the other parameters have their usual meanings. Then, $(4.16 \pm 0.04) \times 10^{-2} \mathrm{~cm}^{2}$ are obtained for the electrochemical areas of the Au working electrodes, suggesting that the variation in the effective areas among the five electrodes in the same measurement is negligible (the relative standard deviation, RSD, less than $2 \%$ ).

Immobilization and Hybridization of DNA. The immobilization and hybridization of DNA were characterized by $\mathrm{CV}$ and DPV using $1.0 \mathrm{mM} \mathrm{K}_{3}\left[\mathrm{Fe}(\mathrm{CN})_{6}\right]$ as an indicator. As shown in Figure 3(a), in the range from $0.55 \mathrm{~V}$ to -0.20 $\mathrm{V}$, there is a well-defined pair redox peaks of $\mathrm{K}_{3}\left[\mathrm{Fe}(\mathrm{CN})_{6}\right]$ in $0.1 \mathrm{M} \mathrm{KCl}$ solution at the bare working electrode (curve a).

The structure of the synthetic thiolated probe DNA is as following:

$$
\begin{aligned}
& \text { 5'-Oligonucleotide-phosphodiester } \\
& \text { bond- }\left(\mathrm{CH}_{2}\right)_{3}-\mathrm{S}-\mathrm{S}-\left(\mathrm{CH}_{2}\right)_{3}-\mathrm{OH}-3 \text { ' }
\end{aligned}
$$

To the aim of producing -SH structure, TCEP was used during the process of immobilization. It is because that TCEP selectively and completely reduces even the most stable water-soluble alkyl disulfides over a wide $\mathrm{pH}$ range. ${ }^{28}$ In our experiments, the efficiency of TCEP was studied in comparison with DTT under the same condition (data not shown). The results indicate that the efficiency of the former is about $120 \%$ higher than that of the later. In addition, TCEP is odor-free and stable in air. Therefore, in all of other experiments TCEP was used rather than DTT.

Two microliters immobilization buffer containing $1.0 \mu \mathrm{M}$ probe 1 DNA was coated onto one of the surface of the $\mathrm{Au}$ disks to prepare a working unit, namely, pDNA1/Au. After a careful rinse, the pDNA1/Au was measured in $1.0 \mathrm{mM}$ $\mathrm{K}_{3}\left[\mathrm{Fe}(\mathrm{CN})_{6}\right]$ and curve $\mathrm{b}$ was obtained. It suggests that probe DNA layer is compact, resulting in not only chemically adsorbed to the Au surface through the thiol end group, but also physically adsorbed to the $\mathrm{Au}$ surface through backbone contacts. ${ }^{29}$ Levicky et al. ${ }^{24}$ also found the presence of multiple contacts between each DNA strand and the surface in this stage. For the sake of high degree hybridization efficiency, end-point attachment of DNA probe is desired. ${ }^{5}$ So, MCH was used to make the end immobilized strands "stand up" and extend farther into the solvent phase. ${ }^{22-24,29}$ Curve $\mathrm{c}$ was the result of the $\mathrm{MCH}+\mathrm{pDNA} 1 / \mathrm{Au}$ measured by CV. It can be seen clearly that a pair welldefined redox peaks appears, suggesting that the access to the surface of the $\mathrm{Au}$ electrode for the electro-active molecular becomes easier in comparison with that at the pDNA1/Au. It's an interesting phenomenon that hasn't been reported previously. We consider that a $\mathrm{MCH}$ monolayer with a terminal hydroxy group forms after the treatment. And this layer is more ready to allow the transit of $\left[\mathrm{Fe}(\mathrm{CN})_{6}\right]^{3-/ 4-}$ than that of compact DNA layer on the pDNA1/Au. The end-tethered HS-ssDNA layer readily hybridizes to its complementary sequence, resulting in DNA helices with a preferred orientation toward the substrate normal. ${ }^{24}$ After the $\mathrm{MCH}+\mathrm{pDNA} 1 / \mathrm{Au}$ hybridizing to 0.15 $\mu \mathrm{M}$ target $1 \mathrm{DNA}$, the $\mathrm{CV}$ response of $1.0 \mathrm{mM} \mathrm{K}_{3}\left[\mathrm{Fe}(\mathrm{CN})_{6}\right]$ was recorded and curve e was obtained. The increase of the $\Delta E_{\mathrm{p}}$ and the decrease of the $i_{\mathrm{p}}$ indicate the successful molecular recognition. If the $\mathrm{MCH}+\mathrm{pDNA} 1 / \mathrm{Au}$ hybridized to target 2 DNA instead of target 1 DNA under the same condition, the obtained working unit was described as
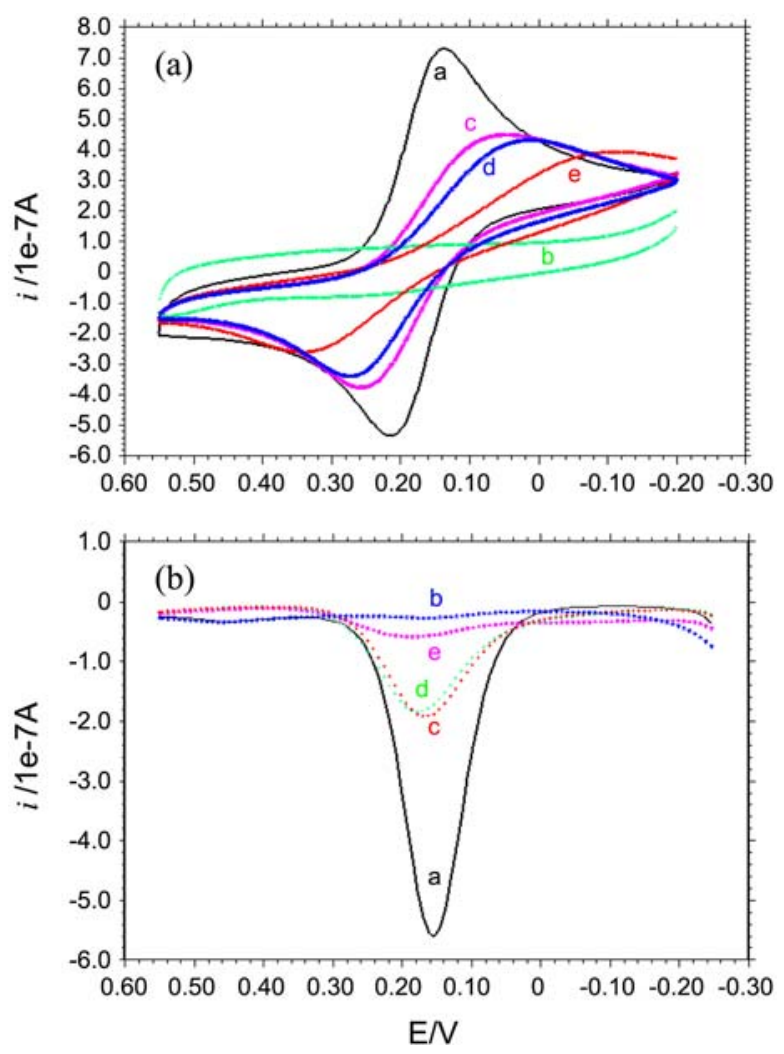

Figure 3. Cyclic voltammograms (A) and differential pulse voltammograms (B) of $1.0 \mathrm{mM} \mathrm{K}_{3}\left[\mathrm{Fe}(\mathrm{CN})_{6}\right]$ at bare Au working electrode (a), pDNA1/Au electrode (b), $\mathrm{MCH}+\mathrm{pDNA} 1 / \mathrm{Au}$ electrode (c), $\mathrm{MCH}+\mathrm{ssDNA} / \mathrm{Au}$ electrode (d) and $\mathrm{MCH}+\mathrm{dsDNA} /$ Au electrode (e). Supporting electrolyte: $0.1 \mathrm{M} \mathrm{KCl}$ solution. Pulse amplitude: $0.05 \mathrm{~V}$; Pulse width: $0.05 \mathrm{~s}$; Pulse period: $0.2 \mathrm{~s}$. Background currents were subtracted. 
$\mathrm{MCH}+\mathrm{ssDNA} / \mathrm{Au}$. From it curve d was obtained. The shape of the curve is similar to that from $\mathrm{MCH}+\mathrm{pDNA} 1 / \mathrm{Au}$, suggesting the unsuccessful molecular recognition. In other words, the $\mathrm{MCH}+\mathrm{pDNA} 1 / \mathrm{Au}$ exhibits good selectivity. This selectivity was investigated further by utilizing mismatched DNA. When one-base mismatch DNA was used for hybridization instead of target $1 \mathrm{DNA}$, the $i_{\mathrm{pa}}$ of the indicator shows a $91 \%$ decrease relative to that at the $\mathrm{MCH}+\mathrm{pDNA} 1 / \mathrm{Au}$. For the use of two-base mismatch DNA, the rate of the decrease is $55 \%$. While for the use of three-base mismatch DNA, the rate of the decrease is $13 \%$, which is the similar case to that when ncDNA is used. These results show further that the selectivity of the hybridizing platform is satisfactory.

As the charging current contribution to the background current is a limiting factor in the analytical determination, experiments of immobilization and hybridization of DNA were also carried out using the DPV mode. As shown in Figure 3(b), the current responses of the indicator show the same rule as that by $\mathrm{CV}$ in various corresponding cases.

The process of immobilization and hybridization of DNA was also characterized by EIS according to the References. ${ }^{14,23,30}$ Curve a in Figure 4 is the Nyquist diagram of $1.0 \mathrm{mM}\left[\mathrm{Fe}(\mathrm{CN})_{6}\right]^{3-/ 4-}$ at the bare Au working electrode. An almost straight line is exhibited, which is a characteristic of a mass diffusional limiting electron-transfer process. In other words, it displays a rather low surface electron-transfer resistance $\left(R_{\mathrm{et}}\right)$. Curve $\mathrm{b}$ is the Nyquist diagram at the pDNA1/Au. The high-frequency section of the curve shows an arc. From this curve a much larger $R_{\text {et }}$ value than that from curve a is obtained owing to much more negative charges of the backbone of pDNA, which blocks the interfacial electron transfer of $\left[\mathrm{Fe}(\mathrm{CN})_{6}\right]^{3-/ 4-} \cdot{ }^{10,14,31}$ After the pDNA1/Au was treated with $\mathrm{MCH}$, the Nyquist diagram is shown as curve c. The $R_{\text {et }}$ value from this curve decreases dramatically compared with that from curve $b$, indicating that negative charges of the $\mathrm{MCH}$ monolayer are less than that compact DNA layer. The Nyquist diagram of $\mathrm{MCH}+$ dsDNA/Au is shown as curve d. It can be seen that the $R_{\text {et }}$

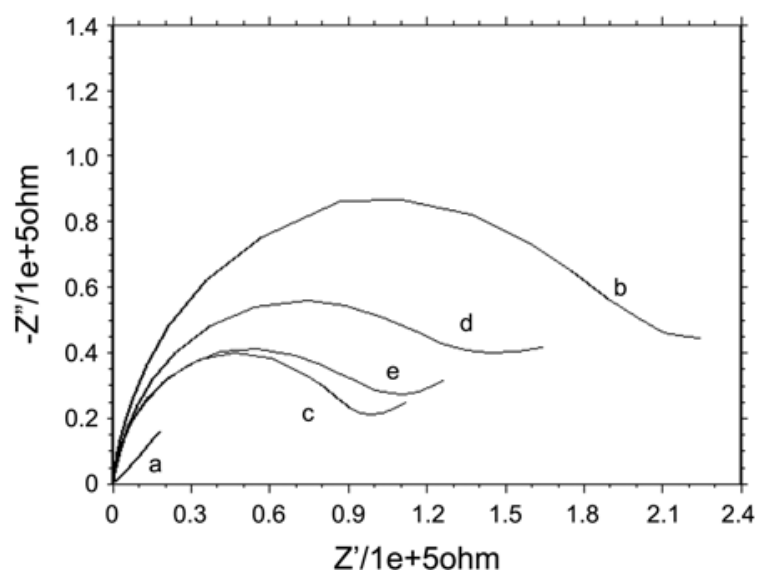

Figure 4. Nyquist diagrams of the bare Au working electrode (a), the pDNA1/Au electrode (b), the MCH+pDNA1/Au electrode (c), the $\mathrm{MCH}+\mathrm{dsDNA} / \mathrm{Au}$ electrode (d) and the $\mathrm{MCH}+\mathrm{ssDNA} / \mathrm{Au}$ electrode (e) in $1.0 \mathrm{mM} \mathrm{K} \mathrm{K}_{3}\left[\mathrm{Fe}(\mathrm{CN})_{6}\right]$. Supporting electrolyte solution: $0.5 \mathrm{M} \mathrm{KCl}$ solution. value increases obviously compared with that from curve c, suggesting the increase of DNA by hybridization. The Nyquist diagram from the $\mathrm{MCH}+\mathrm{ssDNA} / \mathrm{Au}$ is shown as curve $\mathrm{e}$, which is at the near place of curve $\mathrm{c}$. The reason for the small difference between curve e and curve $\mathrm{c}$ is not clear now. It originates probably from the experimental error or adsorption of trace ncDNA. As described above, the EIS experiments are in good accordance with the voltammetric experiments.

Parallelization. The parallelization of the five working units on one chip for the immobilization and hybridization was investigated. For identification, the five working electrodes on one chip were numbered as 1,2,3,4 and 5, respectively. All the five working electrodes were characterized by DPV in $1.0 \mathrm{mM} \mathrm{K}_{3}\left[\mathrm{Fe}(\mathrm{CN})_{6}\right]$ solution. Then they were all immobilized with probe 1 DNA separately to fabricate five $\mathrm{MCH}+\mathrm{pDNA} 1 / \mathrm{Au}$ platforms, followed by being measured in the same way. After hybridization, the five working units were also characterized by DPV. It can be calculated that the RSDs are $1.4 \%, 2.9 \%$ and $7.5 \%$ for the $i_{\mathrm{pa}} \mathrm{s}$ of the indicator at the five bare working electrodes, $\mathrm{MCH}+\mathrm{pDNA} 1 / \mathrm{Au}$ and $\mathrm{MCH}+\mathrm{dsDNA} 1 / \mathrm{Au}$, respectively. The relationship between current responses of the indicator and the measurement cases is shown in Figure 5. On one hand, it is clear that either the parallelization of immobilization or the parallelization of hybridization is satisfactory. On the other hand, the current response of the indicator changes remarkably between before and after hybridization. These results indicate that the present method can be used to recognize target DNA reliably.

The parallelization of the immobilization with different kinds of probe DNA was also investigated. Immobilization buffer solutions, in which $1.0 \mu \mathrm{M}$ probe 1 DNA, probe 2 DNA, probe 3 DNA, probe 4 DNA and probe 5 DNA were contained, respectively, were coated separately onto corresponding number electrodes on one chip under the same condition, followed by the treatment with $\mathrm{MCH}$. The asprepared modified electrodes were described as $\mathrm{MCH}^{+}$

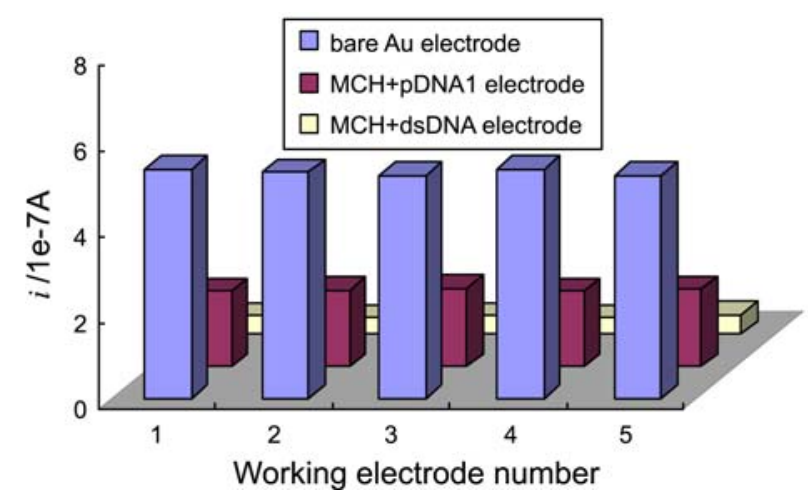

Figure 5. Relationship between the $i_{\mathrm{pa}} \mathrm{S}$ of $\left.1.0 \mathrm{mM} \mathrm{K} 3 \mathrm{Fe}(\mathrm{CN})_{6}\right]$ and the measurement cases at No. 1, No. 2, No. 3, No. 4 and No. 5 working units. For each of the working electrodes the immobilization of probe $1 \mathrm{DNA}$ and hybridization to target 1 DNA were performed under the same condition. Other conditions were the same as in Figure 3(B). 


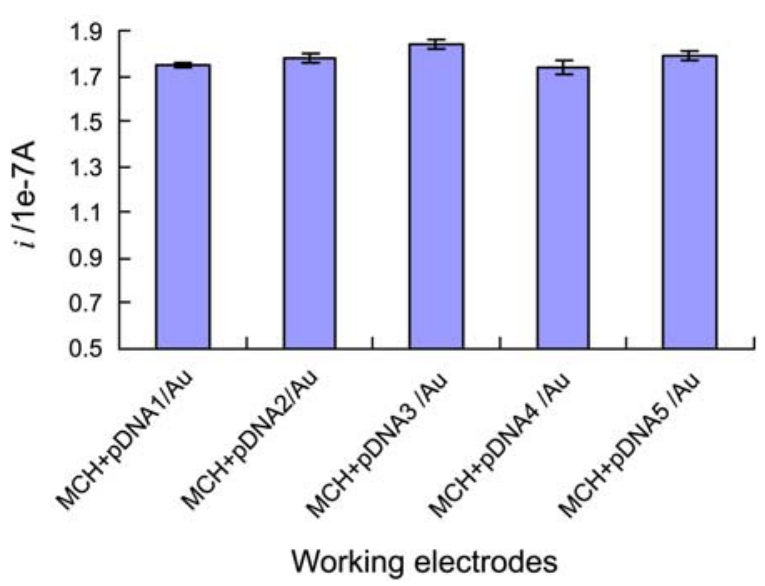

Figure 6. DPV current responses of $1.0 \mathrm{mM} \mathrm{K}_{3}\left[\mathrm{Fe}(\mathrm{CN})_{6}\right]$ at the five working units modified with probe DNA 1, probe DNA 2, probe DNA 3, probe DNA 4 and probe DNA 5, respectively. The different probes were immobilized onto the working electrodes under the same condition $(n=5)$. Other conditions were the same as in Figure 3(B).

pDNA1/Au, $\mathrm{MCH}+\mathrm{pDNA} 2 / \mathrm{Au}, \mathrm{MCH}+\mathrm{pDNA} 3 / \mathrm{Au}, \mathrm{MCH}+$ pDNA4/Au and $\mathrm{MCH}+\mathrm{pDNA} 5 / \mathrm{Au}$, respectively. Then they were recorded by DPV in $1.0 \mathrm{mM} \mathrm{K}_{3}\left[\mathrm{Fe}(\mathrm{CN})_{6}\right]$ solution separately. The $i_{\mathrm{pa}}$ of the indicator are obtained as shown in Figure $6(n=5$, measured from 5 different chips), suggesting a good parallelization of immobilization with different kinds of probe DNA.

In the experiments, the length for all the probe DNA strands was $28 \mathrm{bp}$. For target 1 DNA and target 2 DNA, it was $25 \mathrm{bp}$. For target 3 DNA, target 4 DNA and target 5 DNA, it was 39 bp. As described above, probe 1 DNA, probe 2 DNA, probe 3 DNA, probe 4 DNA and probe 5 DNA were immobilized separately onto different working electrodes on one chip. After the treatment with $\mathrm{MCH}$, they hybridized with corresponding target DNA separately. Then the chip was washed with water carefully, followed by being measured by DPV in $1.0 \mathrm{mM} \mathrm{K}_{3}\left[\mathrm{Fe}(\mathrm{CN})_{6}\right]$ solution with the same process. It is found that there isn't noticeable difference between the $i_{\mathrm{pas}}$ obtained at the five working units, suggesting that the long target DNA hybridized to the probe DNA doesn't display more negative effect on the redox reaction of the indicator than that of the short one. It is interesting. But the reason is unclear now.

Detection of Target DNA. On one chip all the five working electrodes were immobilized with probe DNA 1 and treated with $\mathrm{MCH}$ under the same condition. Then the immobilized probe DNA hybridized to a series of target DNA 1 with different concentrations ${ }^{10}$ for $45 \mathrm{~min}$. Sequentially, all the working units were recorded by DPV in $1.0 \mathrm{mM}$ $\mathrm{K}_{3}\left[\mathrm{Fe}(\mathrm{CN})_{6}\right]$ solution. As showed in Figure 7, the plot of the measurement signal $\left(i_{\mathrm{pa}}\right)$ versus the target DNA concentrations is a straight line $(\mathrm{r}=0.990)$ in the range of $56-162$ $\mu \mathrm{M}$ with a detection limit of $32 \mu \mathrm{M}(\mathrm{S} / \mathrm{N}=3)$.

Simultaneous Detection of Multiple DNA. Simultaneous detection of different kinds of target DNA was also investigated. On one chip each of the working electrodes was

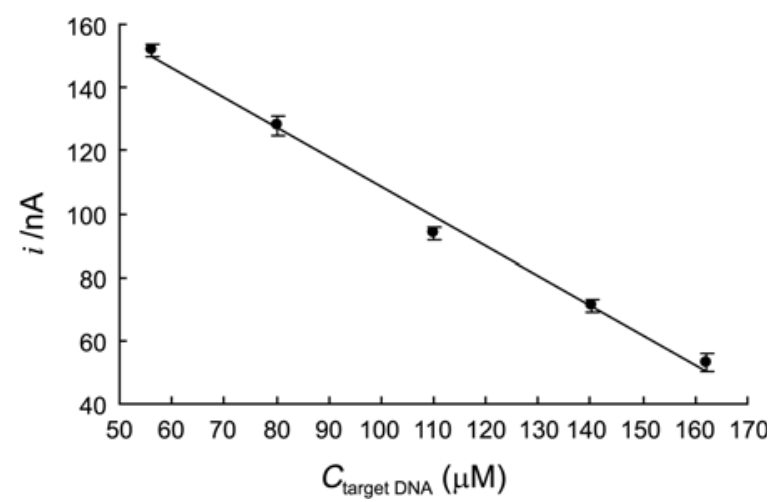

Figure 7. The plot of $i_{\mathrm{pa}}$ of $1.0 \mathrm{mM} \mathrm{K}_{3}\left[\mathrm{Fe}(\mathrm{CN})_{6}\right] v s$. target DNA concentrations $(n=5)$. Other conditions were the same as in Figure 3(B).

immobilized with one kind of probe DNA separately. After the treatment with $\mathrm{MCH}$, the cavity of the chip was covered with $10 \mu \mathrm{L}$ hybridization buffer solution containing $0.15 \mu \mathrm{M}$ each kind of target DNA. After an incubation for $45 \mathrm{~min}$, the platform of the chip was washed carefully, followed by being measured by DPV immediately. The values of $i_{\mathrm{pa}}$ of $1.0 \mathrm{mM} \mathrm{K}_{3}\left[\mathrm{Fe}(\mathrm{CN})_{6}\right]$ at all the five working units vary from $66 \mathrm{nA}$ to $87 \mathrm{nA}$. They are noticeably larger than that detection of target 1 DNA separately ( $40 \pm 3 \mathrm{nA})$, suggesting an obvious interactional interference for the recognition reaction. Further investigation shows that a limit of $70 \mathrm{nM}$ $(\mathrm{S} / \mathrm{N}=3)$ can be obtained for the detection of target DNA 1 in the presence of $600 \mathrm{nM}$ coexisting ncDNA. This is a little higher than that reported previously. ${ }^{2}$

Application in the Detection of LAMP Products. On one chip, probe $\mathrm{B}$ and probe $\mathrm{F}$ related to WSSV gene were immobilized onto two of the working electrodes, respectively. At the same time, a mismatch probe was immobilized onto another working electrode, keeping the rest two working electrodes clean. After the hybridization, the five electrodes were scanned by DPV under the same condition mentioned above. The values of $i_{\mathrm{pa}}$ of $1.0 \mathrm{mM} \mathrm{K}_{3}\left[\mathrm{Fe}(\mathrm{CN})_{6}\right]$ at all the two clean working units were about $535 \mathrm{nA}$. While it was $71 \mathrm{nA}$ at the mismatch probe modified electrode. As expected, at the probe $\mathrm{B}$ and probe $\mathrm{F}$ modified electrodes, it decreases noticeably (about $51 \mathrm{nA}$ ), suggesting a successful recognition reaction. This significant difference of the signals confirms that this DNA biosensor can effectively detect the LAMP products.

\section{Conclusions}

Five Au working electrodes array were fabricated on a chip by photolithography technique. And the electrochemical properties of the chip were characterized. Based on the results, it was used to fabricate DNA arrays by assembling probe DNA related to WSSV gene via Au-S function. Using potassium ferricyanide as electrochemical indicator, the device could be used to recognize reliably not only synthetic sequence-specific DNA but also LAMP products. Though the detection limit of target DNA is larger than that obtained 
at solo DNA sensor as outlined in the references, ${ }^{7-10,32}$ this can be developed by using some special indicators, such as Hoechst $33258,{ }^{4,33}\left[\mathrm{Ru}\left(\mathrm{NH}_{3}\right)_{6}\right]^{3+20}$ and so on. In fact in this study we focus on many other attractive advantages of the electrochemical chip. First, it is small enough to prepare portable device. Second, the fabrication of the DNA array is simple. Thus, the cost is low for a mass manufacture. Third, the parallelization of the working units on the chip is satisfactory. Finally, it can be used to quantificationally detect five kinds of target DNA by one recognizing process. Namely, it's a real time-saver in comparison with DNA sensors for complex samples testing. Therefore, it opens the door for real "rapid detection". All in all, we expect that this device will enable the DNA analyzing to be more easy, rapid and low-cost.

Acknowledgments. This work was supported by the National Natural Science Foundation of China (Grant No. 21005086) and the National High Tech Research and Development Program of China (863 program) (2006AA100306).

\section{References}

1. Levinea, P. M.; Gonga, P.; Levicky, R.; Shepard, K. L. Biosens. Bioelectron. 2009, 24, 1995.

2. Moeller, R.; Fritzsche, W. IEE Proc-Nanobiotechnol. 2005, 152, 47.

3. Dill, K.; McShea, A. Drug Discov. Today Tech. 2005, 2, 261

4. Choi, Y.-S.; Park, D.-H. J. Korean Phys. Soc. 2004, 6, 1556.

5. Odenthal, K. J.; Gooding, J. J. Analyst 2007, 132, 603.

6. Wang, J. Biosens. Bioelectron. 2006, 21, 1887.

7. Zhu, N.; Gu, Y.; Chang, Z.; He, P.; Fang, Y. Electroanalysis 2006, 18, 2107.

8. Wang, J.; Kawde, A.-N.; Musameh, M. Analyst 2003, 128, 912.

9. Ariksoysal, D. O.; Karadeniz, H.; Erdem, A.; Sengonul, A.; Sayiner, A. A.; Ozsoz, M. Anal. Chem. 2005, 77, 4908.

10. Jiao, K.; Yang, T.; Yang, J.; Feng, Y. Sci. China Ser. B 2007, 50, 538.
11. Yeung, S. S. W.; Lee, T. M. H.; Hsing, I.-M. Anal. Chem. 2008, $80,363$.

12. Wang, J. Nucleic Acids Res. 2000, 28, 3011.

13. Cagnin, S.; Caraballo, M.; Guiducci, C.; Martini, P.; Ross, M.; SantaAna, M.; Danley, D.; West, T.; Lanfranchi, G. Sensors 2009, 9,3122 .

14. Zhang, X.; Jiao, K.; Liu, S.; Hu, Y. Anal. Chem. 2009, 81, 6006.

15. Service, R. Science 1998, 282, 396

16. Goto, K.; Horiuchi, H.; Shinohara, H.; Motegi, K.; Hashimoto, K.; Hongo, S.; Gemma, N.; Hayashimoto, N.; Itoh, T.; Takakura, A. J. Microbiol. Meth. 2007, 69, 93.

17. Liang, Y.; Huang, J.; Song, X.; Zhang, P.; Xu, H. Dis. Aquat. Org. 2005, 66, 81 .

18. Yan, D.; Dong, S.; Huang, J.; Yu, X.; Feng, M.; Liu, X. Dis. Aquat. Org. 2004, 59, 69

19. Gooding, J. J. Electroanalysis 2002, 14, 1149.

20. Zhang, J.; Song, S.; Zhang, L.; Wang, L.; Wu, H.; Pan, D.; Fan, C. J. Am. Chem. Soc. 2006, 128, 8575.

21. Pandey, C. M.; Singh, R.; Sumana, G.; Pandey, M. K.; Malhotra, B. D. Sens. Actuators B 2011, 151, 333.

22. Steel, A. B.; Herne, T. M.; Tarlov, M. J. Anal. Chem. 1998, 70, 4670.

23. Zhang, S.; Zhong, H.; Ding, C. Anal. Chem. 2008, 80, 7206.

24. Levicky, R.; Herne, T. M.; Tarlov, M. J.; Satija, S. K. J. Am. Chem. Soc. 1998, 120, 9787.

25. Zhang, Q.; Shi, C.; Huang, J.; Jia, K.; Chen, X.; Liu, H. J. Virol. Meth. 2009, 158, 18.

26. Sun, W.; Qin, P.; Gao, H.; Li, G.; Jiao, K. Biosen. Bioelectron. 2010, 25, 1264

27. Harrison, D. E.; Taube, H. J. Am. Chem. Soc. 1967, 89, 5706.

28. http://www.piercenet.com/Products/Browse.cfm?fldID= 02051012\&WT.mc id=go TCEP TCEP pf\&gclid=CKjj0oLRx qICFQ0dewodfhS9HA.

29. Kim, J. H.; Hong, J.-A.; Yoon, M.; Yoon, M. Y.; Jeong, H.-S.; Hwang, H. J. J. Biotechnol. 2002, 96, 213.

30. Li, A.; Yang, F.; Ma, Y.; Yang, X. Biosens. Bioelectron. 2007, 22 , 1716.

31. Cai, H.; Xu, Y.; He, P.; Fang, Y. Electroanalysis 2003, 15, 1864.

32. Kerman, K.; Morita, Y.; Takamura, Y.; Ozsoz, M.; Tamiya, E. Electroanalysis 2004, 16, 1667.

33. Hashimoto, K.; Ito, K.; Ishlmori, Y. Anal. Chem. 1994, 66, 3830. 